東京の山地河川でのM T M モデルによる洪水流出解析 Flood Runoff Analysis for Mountain basins Rivr in Tokyo Using a $\mathrm{M} \cdot \mathrm{T} \cdot \mathrm{M} \operatorname{modeI}$

$\begin{array}{llr}\text { 東京都土木技術研究所 } & \text { 正員 } \bigcirc \text { 土屋 } & \text { 十图 } \\ \text { 新潟大学 工学部 } & \text { 正員 岡本 } & \text { 芳美 } \\ \text { 東京都土木技術研究所 } & \text { 正員 和泉 清 }\end{array}$

\title{
1.はじめに
}

東京の西多摩地域は多摩川本川上流域、秋川、平井川、及び日原川等の山地河川があり、昭和 57 年 8 月の 台風10号にょる豪雨て、近年てない規模の河川災害が発生した。現在、てれらの河川の改修計画は低地部を 比較的多くもつ平井川を除いて準備されていない。しかし、近年、ての水系で東京のリクリエーション地 域としてつり人口の増大、多摩地域への開発に伴ら市街地のスプロール化等によって、適格な河川情報の层 達、洪水予測の必要性が重要な課題となっている。東京都としては、従来、河道計画のための洪水流出解析 は合理式に上って立案して来た。しかし、西多摩地域の上うな山地河川においては、洪水流出現象は二次流 出分が卓越しているため合理式ては減水部ての同定化が難しいてとが予想される。したがって、本報ては、 流域の特性值を知るだけて、流域每の定数パラメータが設定てを、降雨流出現象のような非線形現象ても、 流域ての適格な分割に上って、現象は線形現象とみなせる上らになるなと、流域の分割が基本となっている M T M モデル（Muluti-Tark Matrix-Model）を使って、洪水流出解析を試み、評価を行ったるのである。

\section{2. 流域の概要と流域解析}

本報の対象河川である流域の概況は表一1、及 表 -1 流域の諸元 び図ー1に示すとおりてある。多摩川（小河内ダ ム〜万年橋）は奥多摩湖にその源を発し、流域面 積 $112.2 \mathrm{~km}$ て、流域内に小河内、奥多摩の 2 ヶ所 の雨量観測所を有し、地形は上流の大起伏山地か ら下流の万年橋付近の丘陵地 (市街地) 飞大をく

\begin{tabular}{|c|c|c|c|c|c|c|c|}
\hline 藏 & $m$ & 名 & 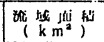 & 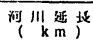 & 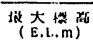 & 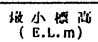 & 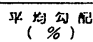 \\
\hline \multicolumn{3}{|c|}{ 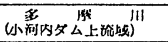 } & 262.9 & 55.1 & 2024 & 600 & 2.58 \\
\hline \multicolumn{3}{|c|}{ 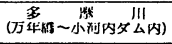 } & 112.15 & 29.2 & 1070 & 140 & 3.18 \\
\hline 秋 & & III & 166.3 & 38.2 & 940 & 98 & 2.20 \\
\hline$\Psi$ & 非 & $m$ & 38.1 & 18.5 & 370 & 110 & 1.40 \\
\hline 日 & 原 & III & 93.8 & 21.1 & 1370 & 340 & 4.88 \\
\hline
\end{tabular}
変化し、地質子古性層、中性層加第 4 紀層（推積岩）まて変化している。以下、地形、地質につらての分 類図は、図ー2〜3亿示す、日原川は東京都西多摩郡の埼玉県境にその源を発し、流域面積 $93.8 \mathrm{~km}$ 流域内に 天祖山、日原の 2 ケ所の雨量観測所を有し地形は大起伏山地て、地質は主に古生層てある。栃久保地点て多 摩川と合流する。秋川懊多摩湖付近と山梨県境にその源を発し、流域面積 $166.3 \mathrm{~km}$ て、地形は多摩川流域

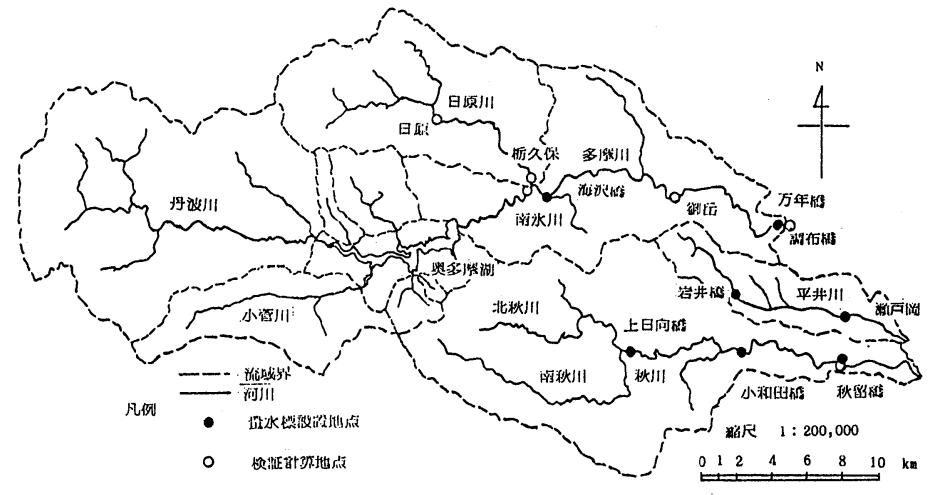

図-1 調査対象流域と量水標設置地点
とほ隹同様である。地質は主に、 中生層の推積岩である。平井川は 多摩川、秋川摤まれ西多摩郡の 日の出山付近にその源を発し、流 域面積は $38.1 \mathrm{~km}$ であり、地形は上 流部の小起伏山地から下流の水田、 市街地をで変化し、山地面積率は 4 河川のうち最も小さい。地質は 古生層から下流の変成岩へと変化 し、土地利用は下流部で畑地、水 田、市街地が広がる。

本研究では M T M 法に用いる多 
摩川流域等の定数パラメーターの值を求め るために $1 / 50,000$ と $1 / 200,000$ 地形図と 土地分類図の中の地形分類図、表層地質図、 土壤図、土地利用現況図を基礎資料として、 地形分類、土壤、地域分類、土地利用現況 図を作成した。

流出計算を行らにあたり $1 / 50,000$ の地 形図にるとつき 4 河川について副流域と残 流域に分割し、河道を含むモデル在各河川 毎に作成した。図ー4 亿は日原川における 流出計算モデルを示す。分割された副流域、 残流域につんて計算に必要な山地の流域面 積、山地面積率、地質、傾斜土地利用現況 等の諸元を計測した。

\section{3. 雨量解析}

雨量資量については、昭和 47 年から同 57 年まての 11 年間のデータから19雨量観測所 毎の一連雨量 ( 24 時間以上無降雨の場合は
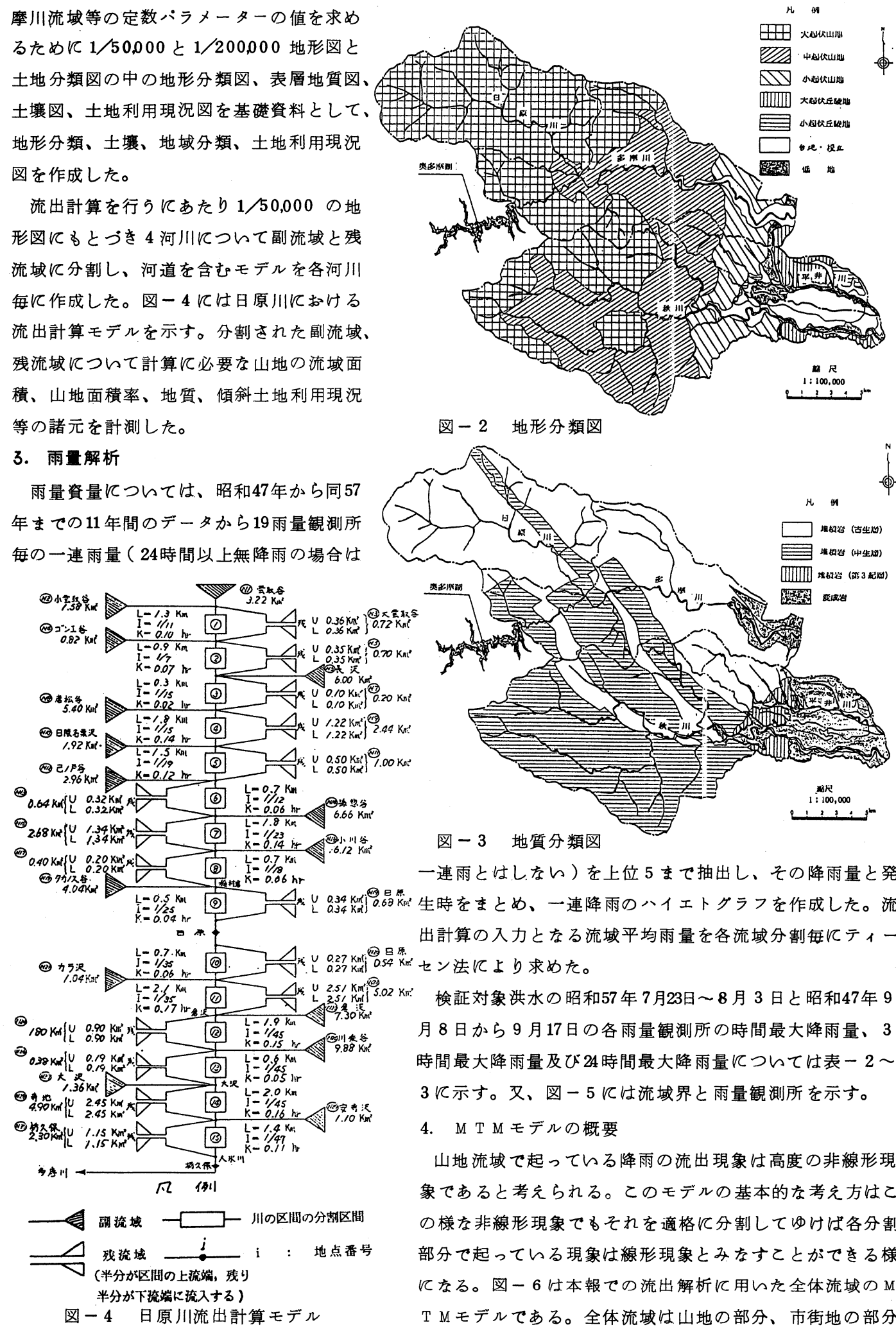

図一 2 地形分類図

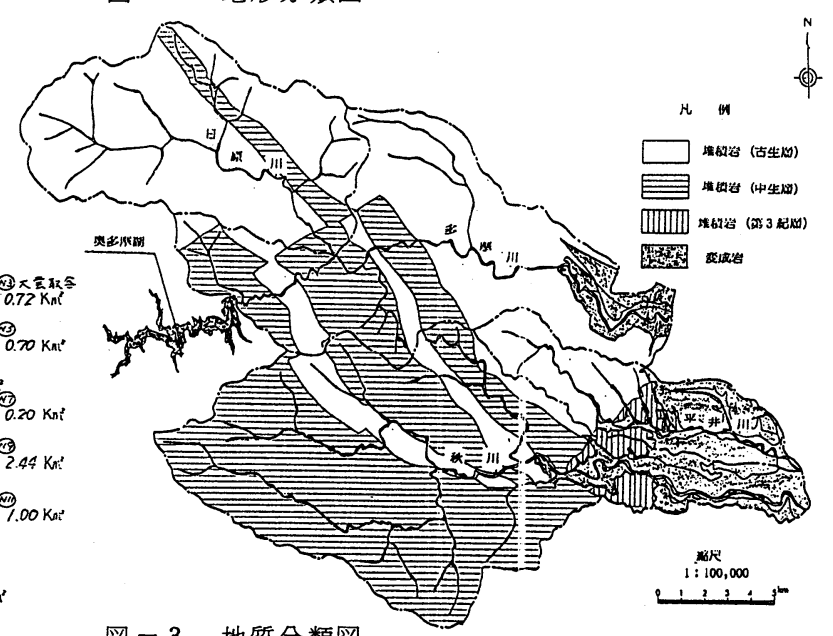

図一 3 地質分類図

一連雨とはしない）を上位 5 まて抽出し、その降雨量と発 生時をまとめ一連降雨のハイエトグラフを作成した。流 出計算の入力となる流域平均雨量を各流域分割毎にティー セン法により求めた。

検証対象洪水の昭和 57 年 7 月23日 8 月 3 日と昭和 47 年 9 月 8 日から 9 月 17 日の各雨量観測所の時間最大降雨量、 3 時間最大降雨量及び 24 時間最大降雨量については表一 2 3 亿示す。又、図ー5 亿は流域界と雨量観測所を示す。

4. M T M モ゙ルの概要

山地流域で起っている降雨の流出現象は高度の非線形現 象である考えられる。このモデルの基本的な考え方はこ の様な非線形現象ですそれを適格に分割してゆけば各分割 部分で起っている現象は線形現象とみなすてとがでをる様 になる。図ー6は本報ての流出解析に用いた全体流域の M T M モデルである。全体流域は山地の部分、市街地の部分、 


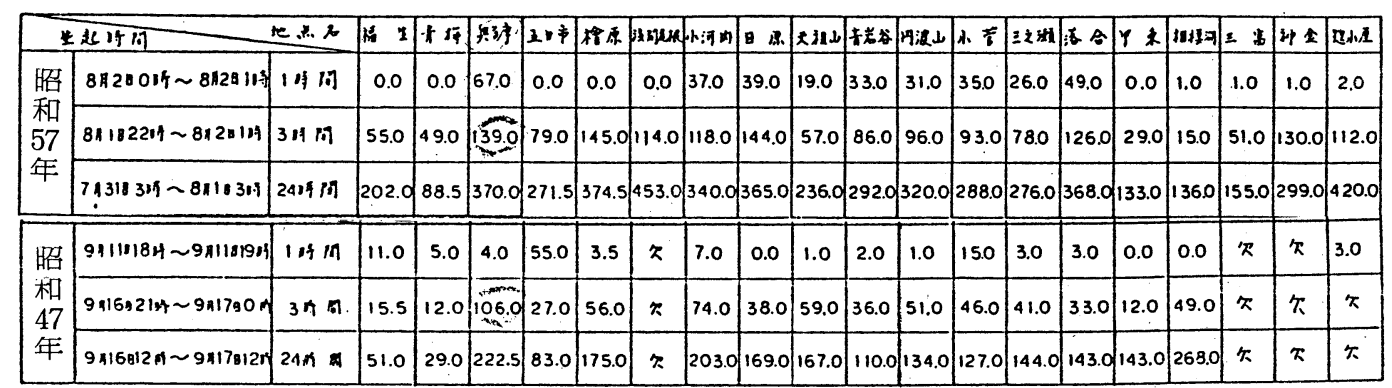

表 $-2 、 3$ 昭和 57 年、昭和 47 年洪水時等雨量 (単位: $\mathrm{mm}$ )

水田地の部分から構成されて いる。ここては、山地の部分 が流出解析を強く支配するた め、市街地及び水田地の部分 の説明は割愛し、山地の部分 を中心に以下述べるとととす る。

山地の部分は山林地帯、無 林地带、河道地带に分けられ る。すず、最上段にあるのが 樹冠層の遮断作用とそてから 蒸発をあらわす部分モデルで タンクに雨水が貯まるととが 遮断作用、流出孔からの流出 が雨水の大気中への蒝発をあ

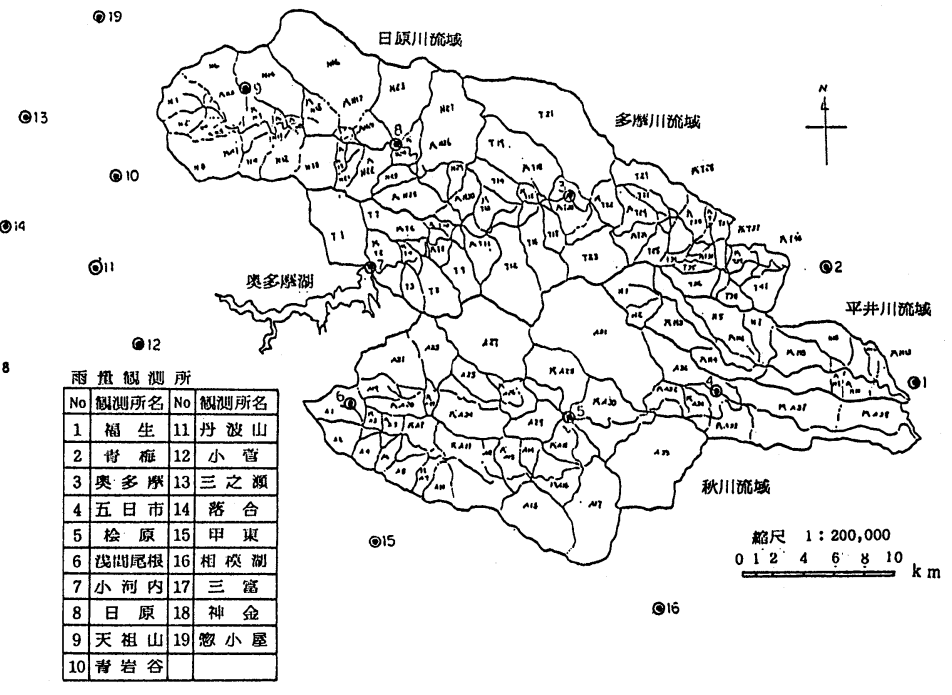
らわし、溢流が地表面をおお ら落葉層への雨水の落下をあ 図 - 5 雨量観測所と流域界

らわしている。第 2 段にあるのが落葉層の遮断作用とそてからの蒸発をあらわす部分モデルて、樹冠層の部 分モデルと全く同じである。第 3 段目にあるのが山林地の土壤が土の湿りとして雨水を保留し、をた樹木の 成長によって、発散作用等で戻って行くことをあらわす部分モデルて、タンクの梁さが最大保水量、流出孔 からの流出量が発散量、溢流頂からの流出量が山林地帯て発生する有効雨量となる。第 4 段目のタンクが土 壤水帯の部分である基本的には三段構造をしていて、一番上には立て坑と流出孔のついたタンク、真中に は節い目と流出孔のついたタンク、一番下には溢流頂と流出孔のついたタンクが重なっている。一番上のタ ンクは土壤水帯が雨水を土の湿りとして保留するてとを表わし、中段のタンクは雨水が土壤水帯から中間帯 に向け浸透するのが妨げられ、地表面に現われることを表わしている。下段のタンクは雨水が土壤水帯を通 過して次の過程に移る間に土壤水帯で限定的を抑留作用を受けるととを表わしている。上段のタンクの深さ は土壤水帯で起こる土の湿りの不足の最大量を表わし、溜った雨水の流出孔からの流出は土壤水帯が土の湿 りとして保持していた水分が発散作用により吸ら上げられ土の湿りの不足が発生するてとを表わしている。 上段のタンクの梁さは土壤水帯て起こる土の湿りの不足の最大量を表わし、溜った雨水の流出孔からの流出 は土壤水帯が土の湿りとして保持していた水分が発散作用により吸ら上げられ土の湿りの不足が発生するて とを表わしている。流出孔から流出する雨水の量、すなわち発散量は蒸発散能の一定割合とする。立て坑に 流れ込んだ雨水が有効雨量となる。

中段のタンクの篩ら目を抜けなかった分が地表面を流れる雨水、笠い目を通り抜けて流出孔ょり流れ出た 


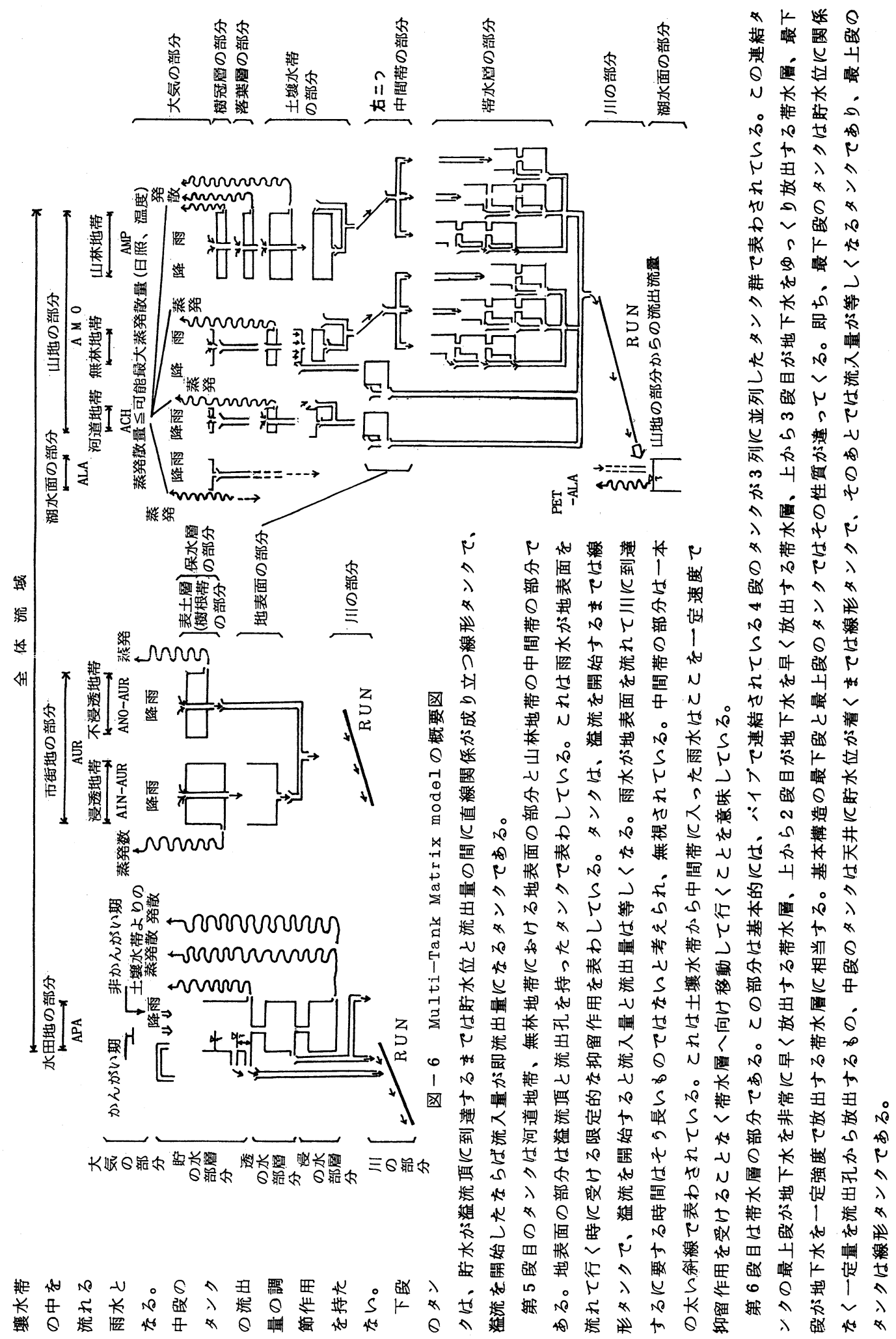


中間帯から移って来た雨水は、連結したタンクの上のタンクが空の時にはそてを通過して下のタンクに入 る。下のタンクが满杯状態においてその流出孔から流出した部分は、ただちに上のタンクの貯水と中間帯から 移って来た雨水のいうれか、また耐方に上って補給されるるのとする。下のタンクの流出孔からの流出量 はその上にあるタンクにその貯水から雨水の補給を受けるといら点を除いては全然影響を受けない。ての部 分の連結タンクは左から第 1 列は早い地下水流出地带、第 2 列は普通の地下水流出地带、第 3 列は安定した 地下水流出地带飞各々相当する。

最後に川の部分である。ての川の部分は一本の斜線で表わされている。てれは斜面の部分から川の部分へ 流れ出た雨水が流域の出口へ向け流れ下って行く状況を表わしている。雨水は川の部分を、河床勾配に応じ た速度て流れ下って行くものと考える。

\section{5. 検証計算結果}

\section{(1) パラメーターの設定}

流域面積（AR E ）、山林地带面積率（AM F ）など地形、土地の状況に関するパラメータは地形図、土

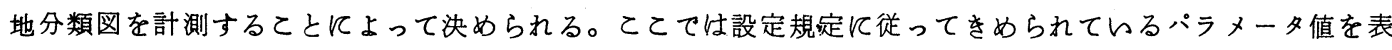
- 4 亿示す。主要なバラメーターとして、D S S 表ー4 検証計算で用いたパラメーター臨表

は土壤水地带標準厚さ、PE T - C O R は樹冠層 蒸発発散係数、K S O-A M F は山林地带の土壤 水帯抑留係数 $20 \mathrm{hr}$ 程度をとる。次に、山地の地下 の带水層の部分をあらわすバラメーターとしては、 I S L - A F A は早地下水流出地带の地下水を 早く放出する帯水層の厚さ、L S L - A M D 忚 下水をっくり放出する带水層の厚さであり、工 S L - A M D は普通の地下水流出地带の地下水を ゆっくり放出する帯水層の厚さである。

(2) 川の区間の流れの計算

川の区間の流れの計算は流出計算に対して独立 なるのてある。図4亿示した流域の河川綱図を

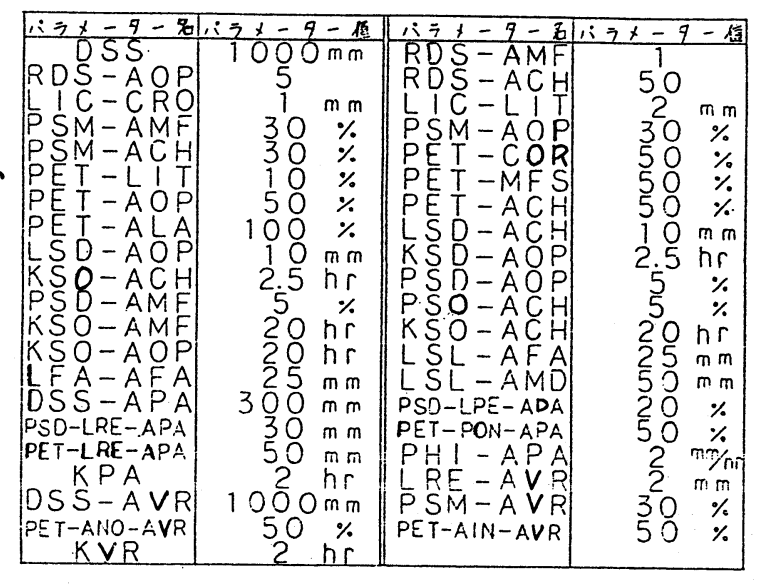
作成する。副流域と残流域に分割されて、副流域の場合は普通の支川をるつ流域であるから M T M 法の適用 ては問題はない。しかし、残流域は、雨水がの区間に沿ら斜面から川を経ないで川の区間に直接的に流れ込 み、空間不等流 (spatilly vaied flow) 形成するすのと考充られる。てのため、いま、地点i - 1 と iの間の分割区間の残流域の流域面積を $\mathrm{A}(\mathrm{km})$ 、区間距離を $\mathrm{L}(\mathrm{km})$ とすると、川から残流域までの平均

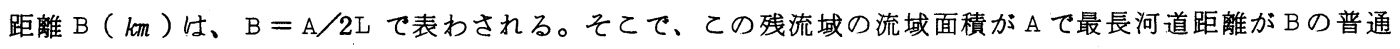
の流域と見なして、M T M 法て流出計算を行った。計算された流出流量の半分が地点i-1飞残り半分が地 点iに集中して流れ込むものとした。ての際、ての仅想の流域の単位集中流量図の作成に当ってはBとい5 長さの一本の川沿いに流域面積が等分布しているすのと仮定した。

山地を流れる川は急勾配をため、係数法を用いた。河道眝流量 S は流出量 Oに対して直接比列すると仮定 し、 $S=K \cdot O(\mathrm{~K}$ は係数て $\mathrm{hr}$ ）－(1) 又、川のある区間を考えると、上流端入の流入量を工、下流端から

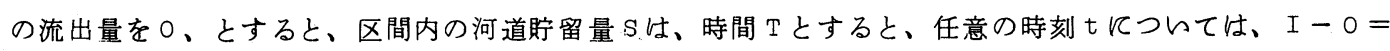
$\mathrm{ds} / \mathrm{dt}-(2)$ となる。この二式により $O_{2}=O_{1}+\mathrm{C}\left(\mathrm{I}_{1}-\mathrm{O}_{1}\right)+\mathrm{C}\left(\mathrm{I}_{2}-\mathrm{I}_{1}\right) / 2 、 乙 て て 、 \mathrm{C}$ 值は、 $\mathrm{C}=\Delta \mathrm{T} /(\mathrm{K}+0.5 \Delta \mathrm{T})$ て、係数 $\mathrm{K}$ は、区間に流九込んだ流れが、そてを通過するに要する時間と考久 られる。そこて、区間距離をし $(\mathrm{km}) 、$ 、間平均河床勾配を $1 /$ Iとして、河床勾配と流下速度の関係はルジ の值より通過速度 $\mathrm{V}(\mathrm{km} / \mathrm{hr})$ を求めて、 $\mathrm{K}=\mathrm{L} / \mathrm{V}$ 式によりKの值を算出した。

\section{(3) 計算開始条件亡検証流量}


計算開始時流量は、計算開始時の比流 量を求め、副流域、残流域の流域面積に 乗じて求められるべをであるが、本報て は、検証のための水位記録を基にして決 定した。蒸発散量は対象とした洪水が短 期流であため無視して計算を行った。 計算開始時流量は多摩川が昭和 57 年て 59 $\mathrm{m}^{3} / \mathrm{s}$ 、同 47 年て $53 \mathrm{~m}^{3} / \mathrm{s}$ 。秋川、平井川 は各年とも $45 \mathrm{~m}^{3} / \mathrm{s} 、 11 \mathrm{~m}^{3} / \mathrm{s}$ とした。 また、土の湿り不足量は 7 月 23 日以前の 1 週間に降雨があったため、各河川とも $0.0 \mathrm{~mm}$ とした。検証計算流量は、実測值 が望ましいが、当河川では、水位記録だ けであることから、現地の実測から、マ ニング式にょり流量を推算し、検証流量 （実測値）とした。昭和57年の洪水ては 小河内ダムの放流があり、検証計算では 放流量を 1 時間平均值とした。以上の計 算結果と実測值を図ー7-10に示した。 各年とも、計算值はピーク流量及びその 時刻で実測值とほぼ一致している。例え ば、多摩川の調布では47年が実測值 1,200 $\mathrm{m}^{3} / \mathrm{s}$ 、計算值 $1,170 \mathrm{~m}^{3} / \mathrm{s}$ であ、 57 年て は各々 $1,500 \mathrm{~m}^{3} / \mathrm{s} 、 1,490 \mathrm{~m}^{3} / \mathrm{s}$ ある。又、 47 年の日原川では、実測值 $216 \mathrm{~m}^{3} / \mathrm{s}$ 、計 算值 $220 \mathrm{~m}^{3} / \mathrm{s}$ となった。しかし、派减部 では計算值の方が早めに落ちている点は、 今后、の課題として残る。

6. おわりに

本報ての検証結果から今後の問題点とし て、流域分割の検討、斜面モデルの出力 である雨量から流量への変換方法の検討 等によって改良するてとが必要と考えら れる。更に、観湘にもとうく実測流量て 検討する予定である。本報を発表するに 当って、資料を提供していただきました 西多摩建設事務所の東野氏には謝意を表 します。

（参考文献）岡本芳美、山地における流 出計算を行 らためのモデル開発研究、第 29 回水理講演会論文集、1 985 . 2 月。

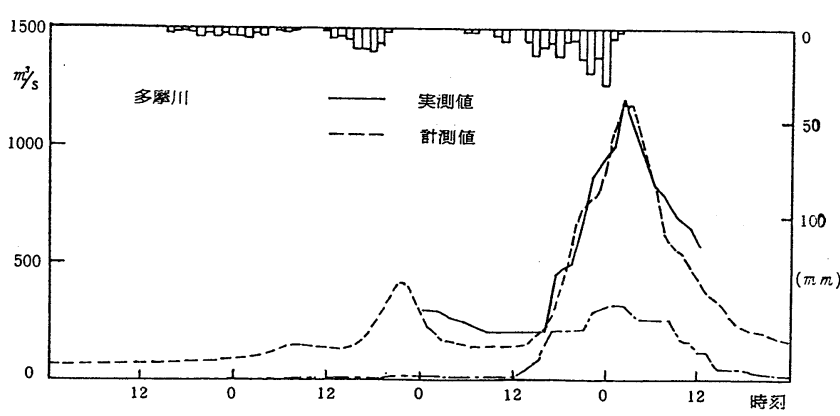

図 - 7 多摩川調布橋地点流出波形（昭和 47 年 9 月洪水）

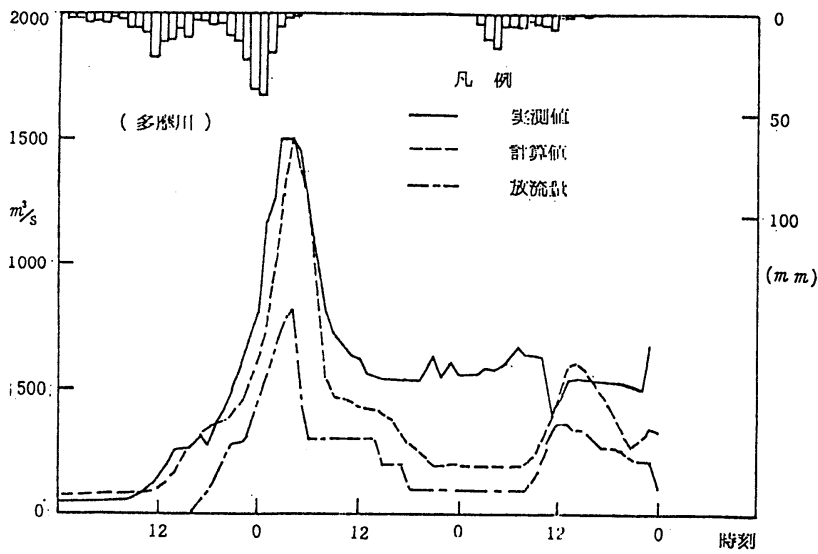

図 - 8 多摩川調布橋地点流出波形（昭和 57 年 8 月洪水）

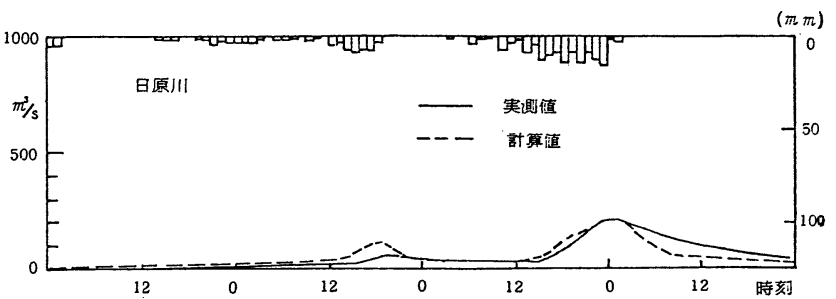

図 -9 日原川日原地点流出波形（昭和 47 年 9 月洪水）

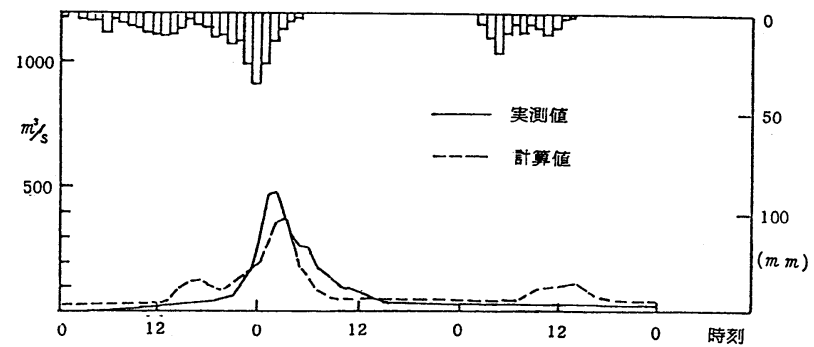

図-10 日原川栃久保地点流出波形（昭和 57 年 8 月洪水） 